\title{
Comparative analysis of the emissions of carbon dioxide and toxic substances emitted by vehicles with ICE compared to the equivalent emissions of BEV
}

ARTICLE INFO

Received: 14 July 2021

Revised: 28 August 2021

Accepted: 30 August 2021

Available online: 9 September 2021

In the article were compared the vehicles (by pairing) the vehicles on the basis of selected criteria considering vehicles': weight, length, wheel width, maximum output and acceleration time. The article was carried out by analysing the available source materials and specific energy mix based on coal. The emission of air pollutants (exhaustive) was estimated using the mathematical calculation. In order to carry out the analysis, the data provided by the manufacturers of the considered cars were used, concerning fuel consumption by the cars equipped with the internal combustion engines or electricity consumption in the case of cars with equipped with electric motors. The air pollutants that were taken into consideration: carbon monoxide, nitrogen oxides, sulphur dioxide, carbon dioxide, and total particulate matter. Apart from the exhaustive emissions, the total particular matter emissions from the tyre and brake wear and road abrasion is also included. The pollutant emission was estimated on the basis of emission factors using the average mileage characterizing for driving in European conditions.

Key words: air pollutant, vehicle, electric vehicle, ICE vehicle, BEV

This is an open access article under the CC BY license (http://creativecommons.org/licenses/BY/4.0/)

\section{Introduction}

The assumptions of the European Green Deal and the pursuit of climate neutrality influence the development of BEV [3, 8-10].

However we can describe electric means of transport as 'ecological', the actual emissions generated by the electric vehicles are associated with the fuel structure occurring in particular country. Then we can say ' $100 \%$ ecological' or 'climate friendly' about vehicles that are powered mainly from renewable energy sources.

According to the last submission of the national air pollutants' emission inventory $[5,6,12]$, Polish energy mix (structure of the fuel combusted) in the public power generation sector consists of $81 \%$ solid fuels, mainly hard coal and lignite. Considering the energy mix, the air emissions from electric vehicles in Poland can be qualified as translation of coal emissions to the road transport sector.

That means the ecological properties of electric vehicles are associated mainly to the national energy mixes in energy production sectors. There are very limited number of scientific publications taking into account comparison between the air pollutants' emissions associated with the $\mathrm{BEV}$, and with ICE vehicles in terms of the energy mix used for electricity production [2,3]. This fact gives an opportunity for investigating the 'ecological side effects' associated with the $\mathrm{BEV}$, and generated as a result of applying of the national energy mix based on the fossil fuels.

\section{Methodology}

The article compares the emission of harmful substances caused by cars which are equipped with: internal combustion engines, and electric motors. Basing on the sets of parameters that affect fuel consumption and, consequently, the emission of harmful substances (descry- bed in three criteria, as below), there are compiled together a pairs of cars (fuel powered vs. electric).

Classification criteria [12]:

1. The ratio of the maximum power output $[\mathrm{kW}]$ to the car's own weight in kilograms. Its aim is to select cars with the most similar engine performance. When the criterion is used for cars with internal combustion engines, it is also named 'balance weight ratio'. The reason for this is the higher (approximately a constant multiple) curb weight of a car with an electric motor compared to its internal combustion counterpart, resulting from the design of the drive. Therefore, in order to obtain a reliable result, this disproportion had to be levelled. Criterion No. 1 has been expressed by the formula (1):

$$
\mathrm{Q}_{1}=\frac{\mathrm{P}}{\mathrm{m} \times \mathrm{q}}
$$

where: $\mathrm{P}$ - maximum power output $[\mathrm{kW}], \mathrm{m}-\mathrm{curb}$ weight of the car $[\mathrm{kg}], \mathrm{q}$ - balance weight ratio for cars with internal combustion engines $=1.215$.

2. Using this criterion it is possible to select cars with the most similar geometrical dimensions, i.e. the length and height of the car. The mentioned parameters also affect the ability to overcome air resistance of a similar value (translating into fuel consumption). The values of which result from a similar maximum power of the engines of the compared cars. Criterion No. 2 has been expressed by the formula (2):

$$
\mathrm{Q}_{2}=\frac{\mathrm{l \times h}}{\mathrm{P}}
$$

where: $\mathrm{P}$ - maximum power output $[\mathrm{kW}], 1$ - length of the car $[\mathrm{m}], \mathrm{h}$ - length and height of the car $[\mathrm{m}]$.

3. The purpose of this criterion is to select cars of the similar rolling resistance and hence of the similar 
energy consumption and emissions. Rolling resistance depends on the tire width and the maximum engine power, as well as the acceleration time. Criterion No. 3 has been expressed by the formula (3):

$$
\mathrm{Q}_{3}=\frac{\mathrm{P}}{\mathrm{w}_{\mathrm{o}} \times \mathrm{t}}
$$

where: $\mathrm{P}$ - maximum power output $[\mathrm{kW}], \mathrm{w}_{\mathrm{o}}-$ tire width $[\mathrm{mm}], \mathrm{t}$ - acceleration time $(0-100) \mathrm{km} / \mathrm{h}[\mathrm{s}]$.

The assumptions for comparing cars with each other were:

- matching a car with an internal combustion engine to a car with an electric engine according to the enumerated criteria,

- finding the results of the criteria in the tolerance field of \pm 0.01 in relation to each other,

- fulfilment of all criteria.

The comparative criteria were selected so that the compared cars were as similar as possible to each other in terms of technical parameters following the design purpose of their use, geometric parameters that affect fuel/electricity consumption, as well as the work performed by engines during operation, which translates into the similar consumption of supplied energy.

In order to obtain meaningful results, both cars (electric vs. fuel powered) of different brands were compared with each other, selecting cars with internal combustion engines from specific ranges of engine displacement i.e. (800-1400) $\mathrm{cm}^{3}$, (1401-2000) $\mathrm{cm}^{3}$ and above $2000 \mathrm{~cm}^{3}$ (Fig. 1) and cars of the same brand (Fig. 2).

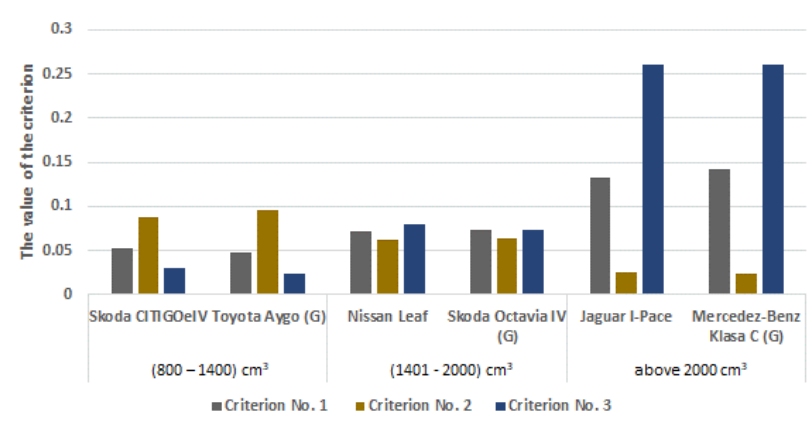

Fig. 1. Summary of the criteria for the selection of cars for testing in terms of engine displacement. $\mathrm{G}$ - gasoline, D - diesel

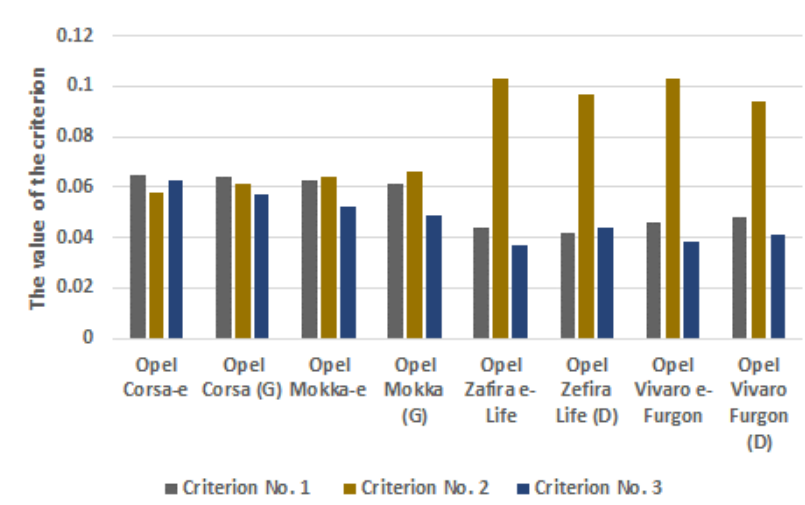

Fig. 2. Summary of criteria for selecting vehicles for testing because of the brand of vehicle. $\mathrm{G}$ - gasoline, $\mathrm{D}$ - diesel
In order to calculate the emissions from the selected ICE vs BEV pairs, the authors calculated the emission of individual harmful substances from combustion processes from a source appropriate for the type of engine for the averaged mileage per year for Polish conditions (including cold start parameter) [4] in a mixed driving cycle.

The emission of $\mathrm{CO}, \mathrm{NO}_{\mathrm{x}}$ and $\mathrm{PM}$ from cars with an internal combustion engine was determined based on the formula (4) [7]:

$$
E_{i, j}=M_{i, k} \times E F_{i, j, k}
$$

where: $E_{i}$ - emission of pollutant $i[g], E F_{i, j, k}-$ emission factor of pollutant $\mathrm{i}$ for vehicle category $\mathrm{j}$ and technology $\mathrm{k}$ (type of fuel and engine displacement) $[\mathrm{g} / \mathrm{veh}-\mathrm{km}], \mathrm{M}_{\mathrm{i}, \mathrm{k}}$ distance driven by vehicle of category $\mathrm{j}$ and technology $\mathrm{k}$ $[\mathrm{km}]$.

The emission of $\mathrm{CO}_{2}$ from cars with an internal combustion engine was determined based on the formula (5) $[1]$ :

$$
\mathrm{E}_{\mathrm{CO} 2}=\mathrm{EF}_{\mathrm{i}, \mathrm{j}, \mathrm{m}} \times \mathrm{FC}_{\mathrm{j}, \mathrm{m}}
$$

where: $E_{i}-$ emission of pollutant $\mathrm{i}[\mathrm{g}], \mathrm{FC}_{\mathrm{j}, \mathrm{m}}-$ fuel consumption of vehicle category $\mathrm{j}$ using fuel $\mathrm{m}$ over the distance driven by vehicle $[\mathrm{g}], \mathrm{EF}_{\mathrm{i}, \mathrm{j}, \mathrm{k}}$ - fuel consumptionspecific emission factor of pollutant $i$ for vehicle category $j$ and fuel $\mathrm{m}[\mathrm{g} / \mathrm{kg}]$.

The emission of $\mathrm{SO}_{2}$ from cars with an internal combustion engine was determined based on the formula (6) [7]:

$$
\mathrm{E}_{\mathrm{SO} 2}=2 \times \mathrm{k}_{\mathrm{s}} \times \mathrm{FC}_{\mathrm{m}}
$$

where: $\mathrm{E}_{\mathrm{SO} 2}$ - emissions of $\mathrm{SO}_{2}$ per fuel $\mathrm{m}[\mathrm{g}], \mathrm{k}_{\mathrm{s}}$ - weight related sulphur content in fuel of type $\mathrm{m}\left[\mathrm{g} / \mathrm{g}_{\text {fuel }}\right], \mathrm{FC}_{\mathrm{m}}-$ fuel consumption of fuel $\mathrm{m}[\mathrm{g}]$

The emission of harmful substances from BEV was determined on the basis of the formula (7) [7]:

$$
\mathrm{E}_{\mathrm{i}}=\mathrm{N} \times \mathrm{EF}_{\mathrm{i}} \times \mathrm{M}
$$

where: $E_{i}$ - emission of pollutant $\mathrm{i}[\mathrm{g}], \mathrm{N}$ - consumption of the electric energy [Wh], $\mathrm{EF}_{\mathrm{i}}$ - emission factor of pollutant $\mathrm{i}$ for electricity produced by installations for combustion of fuels $[\mathrm{g} / \mathrm{Wh}], \mathrm{M}-$ distance driven by vehicle $[\mathrm{km}]$.

For the calculations the following data were used:

- fuel and electricity consumption over a distance (catalogue data),

- emission factors for harmful substances for cars with internal combustion engines [1,7],

- TSP emission factors from the tyre and brake wear and road abrasion [7],

- emission factors of harmful substances by fuel combustion installations [6],

- weight and calorific value of gasoline and diesel oil (catalogue data).

\section{Results}

The described methodology allowed for the selection of cars and carrying out the research using the computational method. The results concerning the emission of pollutants are presented in the Figs 3-6. 


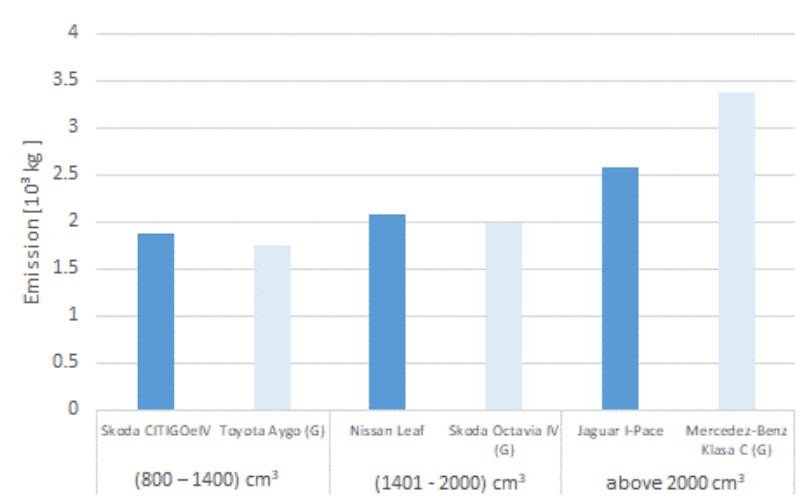

Fig. 3. Comparison of $\mathrm{CO}_{2}$ emissions for the selection of cars for testing in terms of engine displacement. BEV - navy blue, ICE - light blue, G gasoline

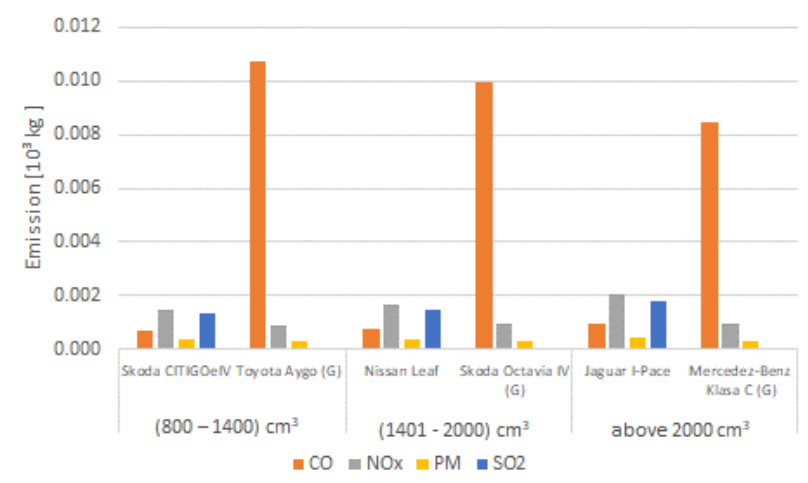

Fig. 4. Comparison of emissions of $\mathrm{CO}, \mathrm{NO}_{\mathrm{x}}, \mathrm{PM}$ and $\mathrm{SO}_{2}$ for the selection of cars for testing in terms of engine displacement. $\mathrm{G}$ - gasoline

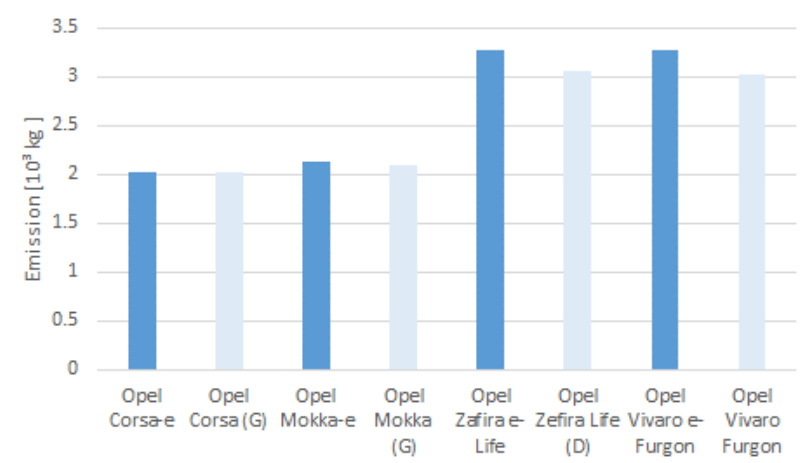

(D)

Fig. 5. Comparison of $\mathrm{CO}_{2}$ emissions of selecting vehicles for testing because of the brand of vehicle. BEV - navy blue, ICE - light blue, G gasoline, D - diesel

\section{Conclusions}

The calculations, as well as the information collected in this article, show that the emissions of carbon dioxide and harmful substances from cars with electric engines and cars with internal combustion engines mainly depend on factors such as:

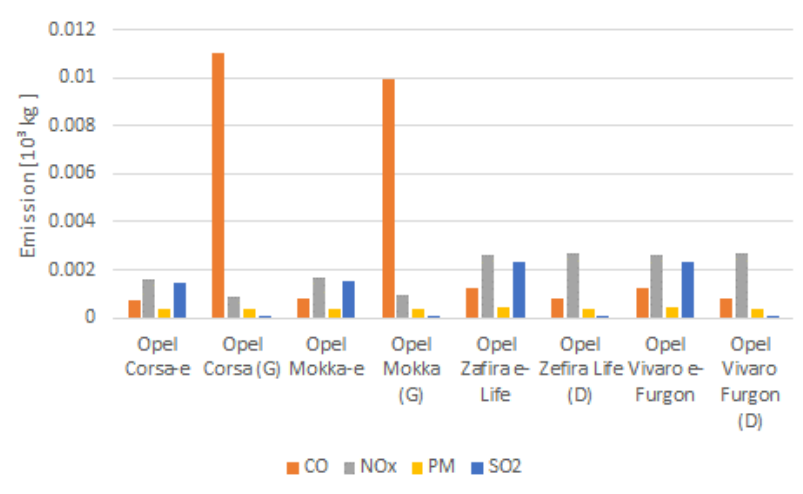

Fig. 6. Comparison of emissions of $\mathrm{CO}, \mathrm{NO}_{\mathrm{x}}, \mathrm{PM}$ and $\mathrm{SO}_{2}$ selecting vehicles for testing because of the brand of vehicle. $\mathrm{G}$ - gasoline, D diesel

- type of internal combustion engine (spark-ignition or compression-ignition),

- displacement of the internal combustion engine,

- energy mix.

After conducting a comparative analysis, it can be concluded that in Polish conditions, introducing cars with electric engines into circulation at the expense of withdrawing cars with internal combustion engines is not unequivocally positive.

This is evidenced by the results obtained which show that the $\mathrm{CO}_{2}$ emission from $\mathrm{BEV}$ is higher than for cars with combustion engines except for the engines of engine displacement above $2000 \mathrm{~cm}^{3}$ (Figs 3 and 5). In the case of $\mathrm{CO}$ emissions, it is clear that for ICEs powered by gasoline, the emissions are higher than for BEVs, but for ICEs powered by diesel, the emissions are lower than for BEVs. For the remaining pollutants, the emissions from ICE are lower than for BEV.

Summing up, the results of the research and the presented analysis of sources show that for the current energy mix in Poland, increasing the number of cars with an electric engine while reducing the number of cars with internal combustion engines will not have a better impact on the natural environment and human health, because the content of $\mathrm{CO}, \mathrm{NO}_{\mathrm{x}}, \mathrm{SO}_{2}$ will increase in the air. In the case of $\mathrm{CO}_{2}$ emissions, it will slightly decrease.

The comparative analysis conducted in this paper can be a reference point for further research on electromobility in the context of the energy mix or electricity and power supply. The aim of the research may be to determine the legitimacy or directions of development of electromobility in terms of its impact on the natural environment and economic aspect. It is also possible to expand the included methodology of comparative analysis to include cars powered by other types of fuels, such as natural gas or biofuels.

\section{Nomenclature}

BEV battery electric vehicle

$\mathrm{CO}$ carbon monoxide

$\mathrm{CO}_{2}$ carbon dioxide

ICE internal combustion engine
$\mathrm{NO}_{\mathrm{x}}$ nitrogen oxides

PM particulate matter

$\mathrm{SO}_{2}$ sulphur dioxide 


\section{Bibliography}

[1] DAVIES WALDRON, C., HARNISCH, J., LUCON, O. et al. Mobile combustion. 2006 IPCC Guidelines for National Greenhouse Gas Inventories. EGGLESTON, H.S., BUENDIA, L., MIWA, K., NGARA, T. et al. (eds), 2006. https://www.ipcc-nggip.iges.or.jp/public/2006gl/index.html

[2] FERNÁNDEZ, R.A. A more realistic approach to electric vehicle contribution to greenhouse gas emissions in the city, Journal of Cleaner Production. 2018, 172, 949-959. https://doi.org/10.1016/j.jclepro.2017.10.158

[3] HOEKSTRA, A. The underestimated potential of battery electric vehicles to reduce emissions. Joule. 2019, 3(6), 1412-1414. https://doi.org/10.1016/j.joule.2019.06.002

[4] MENES, M. Studies results concerning passenger cars' average annual mileages in Poland in 2014. Przeglad komunikacyjny. 2015, 5, 6-10.

http://www.przeglad.komunikacyjny.pwr.wroc.pl/05_2015/ PK_05_15.pdf (in Polish with English abstract).

[5] MINISTRY OF CLIMATE AND ENVIRONMENT. Poland's National inventory report 2020 Greenhouse gas inventory for 1988-2018 Submission under the United Nations Framework Convention on Climate Change and the Kyoto Protocol. 2021. https://unfccc.int/documents/274762

[6] MINISTRY OF CLIMATE AND ENVIRONMENT. Poland's Informative Inventory Report. Submission under the UNECE CLRTAP and NEC Directive. 2021.

https://cdr.eionet.europa.eu/pl/eu/nec_revised/iir/envyei5sq/

[7] NTZIACHRISTOS, L., SAMARAS Z. Road transport. EMEP/EEA air pollutant emission inventory guidebook 2019. 2019, 13. https://doi.org/10.2800/293657

Piotr Laskowski, DEng. - Faculty of Automotive and Construction Machinery Engineering, Warsaw University of Technology.

e-mail:piotr.laskowski@pw.edu.pl

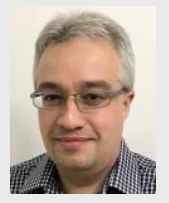

Damian Zasina, DEng. - Faculty of Building Services, Warsaw University of Technology.

e-mail:damian.zasina@pw.edu.pl
[8] RANGARAJU, S., DE VROEY, L., MESSAGIE, M. et al. Impacts of electricity mix, charging profile, and driving behavior on the emissions performance of battery electric vehicles: A Belgian case study. Applied Energy. 2015, 148, 496-505. https://doi.org/10.1016/j.apenergy.2015.01.121

[9] REGULATION OF THE EUROPEAN PARLIAMENT and of the COUNCIL on establishing the framework for achieving climate neutrality and amending Regulation (EU) 2018/1999 (European Climate Law).

https://eur-lex.europa.eu/legal-

content/EN/TXT/PDF/?uri=CELEX:52020PC0563\&from= $\mathrm{EN}$

[10] THE EUROPEAN GREEN DEAL. 2019. Communication from the Commission to the European Parliament, the Council, the European Economic and Social Committee and the Committee of the Regions.

https://eur-lex.europa.eu/legal-

content/EN/TXT/PDF/?uri=CELEX:52012DC0673\&from= EN

[11] WIATRAK, M. Analiza porównawcza emisji dwutlenku węgla i substancji toksycznych emitowanych przez samochody $\mathrm{z}$ silnikami spalinowymi $\mathrm{w}$ porównaniu do równoważnej emisji $\mathrm{z}$ samochodów $\mathrm{z}$ silnikami elektrycznymi. Graduate thesis. Warsaw University of Technology. 2021 (in Polish with English abstract).

[12] Wskaźniki emisyjności $\mathrm{CO}_{2}, \mathrm{SO}_{2}, \mathrm{NO}_{\mathrm{x}}, \mathrm{CO}$ i pyłu całkowitego dla energii elektrycznej, na podstawie informacji zawartych w Krajowej bazie o emisjach gazów cieplarnianych i innych substancji za 2019 rok. Instytut Ochrony Środowiska Państwowy Instytut Badawczy. Warsaw 2020.

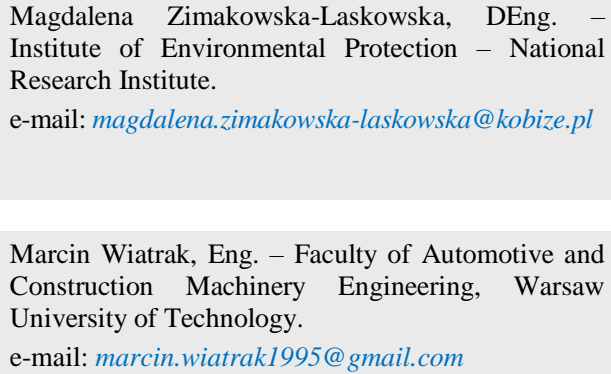

Marcin Wiatrak, Eng. - Faculty of Automotive and

Construction Machinery Engineering, Warsaw

University of Technology.

e-mail:marcin.wiatrak1995@gmail.com

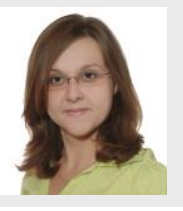

